\title{
FUSCOCEPHALOZIOPSIS CATENULATA (HUEBENER) VÁŇA ET L. SÖDERSTR. - A LIVERWORT NEW TO WIGRY NATIONAL PARK (NORTH-EASTERN POLAND)
}

\author{
Piotr GóRsKI, MACIEJ ROMAŃSKI
}

\begin{abstract}
P. Górski, Department of Botany, Poznań University of Life Sciences, Wojska Polskiego 71 C, 60-625 Poznań, Poland, e-mail: peter@up.poznan.pl

M. Romański, Wigry National Park, Krzywe 82, 16-402 Suwałki, Poland, e-mail: maciej.romanski@wigry. org.pl
\end{abstract}

(Received: February 22, 2016. Accepted: March 21, 2016)

\begin{abstract}
AвSTRACt. This paper presents the distribution of Fuscocephaloziopsis catenulata in Wigry National Park (north-eastern Poland) based on studies conducted during 2014-2015. This species is new to the flora of that area and was documented at 25 inventory sites in eight near-natural forest complexes.
\end{abstract}

KeY WORDs: Fuscocephaloziopsis (= Cephalozia) catenulata, rare species, primeval forest relics, Wigry National Park

\section{INTRODUCTION}

Fuscocephaloziopsis catenulata (Huebener) Váňa et L. Söderstr. (= Cephalozia catenulata (Huebener) Lindb.) is a suboceanic-mountainous species (DüLL 1983). To date, its localities in Poland have been reported in almost all mountain massifs and in the northern (primarily north-eastern) part of the country (SzWEYKowsKi 2006). In the southern part, this liverwort has been reported from the Izerskie Mountains, the Karkonosze Mountains, the Sowie Mountains, Kotlina Jeleniogórska Basin, Beskid Śląski Range, Beskid Żywiecko-Orawski Range, the Babia Góra Massif, the Tatra Mountains (and Podtatrze), the Gorce Mountains, the Beskid Sacdecki Range and the Bieszczady Mountains (SzweYKowski 1958, 1960, Mamczarz 1977, Mierzeńska 1994, Klama 1996, 2004, 2008, SzWEYKowski \& BuczKowsKa 1996, StaNIASZEK-KiK 2010, GóRSKI \& VÁŇA 2014). Lowland localities of $F$. catenulata are found in the Pojezierza and Pobrzeża Południowobałtyckie regions as well as in Pojezierza Wschodniobałtyckie Lakelands, Nizina Północnopodlaska Lowland and Wyżyna Kielecka Upland (the Świętokrzyskie Mountains) and Roztocze region (SzWEYKowski 1958, Klama 2002a, b, GóRSKI 2013, GórsKi in Stebel et al. 2013, GóRSKI \&
PAWLiKowski 2014, GóRski in Fudali et al. 2015). A map of the F. catenulata distribution in Poland based on data in the literature is given in Figure 1.

Fuscocephaloziopsis catenulata is an epixylic species found in near-natural forests with characteristics of a virgin forest (CIEŚLIŃSKI et al. 1996). Based on studies in the Puszcza Białowieska primeval forest, this plant was classified as a so-called primeval forest relic (KLAMA in CieślińsKi et al. 1996, KLAMA 2002b). Aside from $F$. catenulata, this group also includes liverworts i.e., Anastrophyllum michauxii (F. Weber) $\mathrm{H}$. Buch, Crossocalyx hellerianus (Nees ex Lindenb.) Meyl., Lophoziopsis longidens (Lindb.) Konst. et Vilnet, Barbilophozia lycopodioides (Wallr.) Loeske and Plagiochila asplenioides (L. emend. Taylor) Dumort. (Klama 2002b). To date, within this group C. hellerianus and $P$. asplenioides have been reported in the flora of Wigry National Park (WIŚNIEWSKI \& REJMENT 1935). These plants are still found in the analysed area. It must be stressed that despite the relatively large number of bryological studies in Wigry National Park (Wiśniewski \& Rejment 1935, Rejment-GroCHOWSKA \& Mickiewicz 1962, Mickiewicz et al. 1963, Bloch et al. 1979, Karczmarz \& SokoŁowski 1981, 1985, WierzCholska et al. 2010), F. catenulata has not been recorded there. In view of the near-natural character of certain forest complexes in the park and 


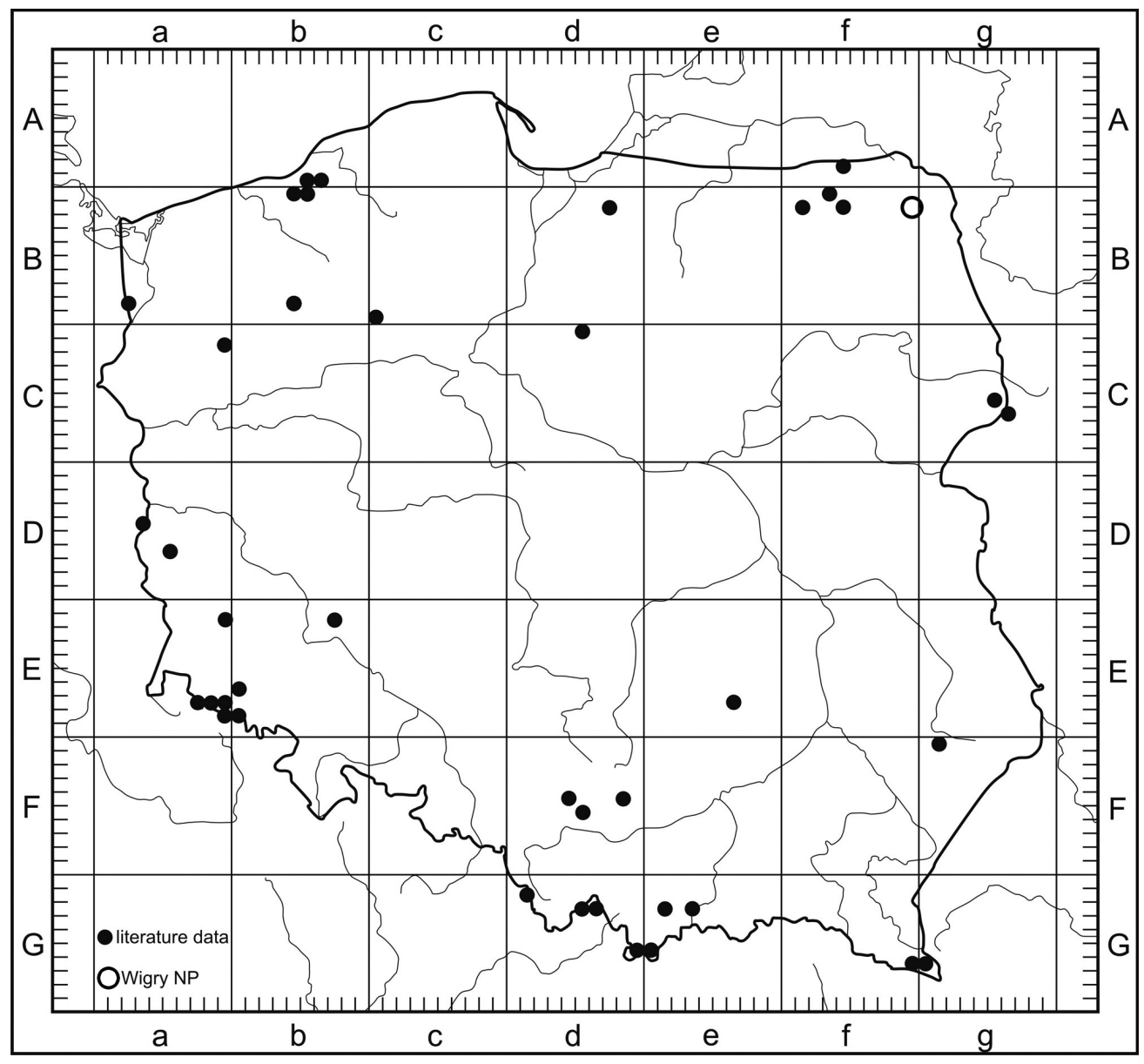

Fig. 1. Distribution of Fuscocephaloziopsis catenulata (Huebener) Váňa et L. Söderstr. in Poland based on literature data

the documented presence of this plant in north-eastern Poland (Klama 2002a, b, GóRski \& Pawlikowski 2014), the occurrence of $F$. catenulata in this area was considered to be highly likely.

It must be stressed here that $F$. catenulata is a rare species in Poland. Despite the relatively high number of localities (compare Fig. 1), most of them were documented before 1960. In some regions of the country, repeated inventories indicated the disappearance of localities of this plant (e.g., in the Śląsk Opolski region or in the Bieszczady Mts; Stebel 2006, KLAMA 2013). It is a threatened species on a national scale - category V (vulnerable; KLAma 2006). The primary threat to this species is associated with the disappearance of large primeval forest complexes in the landscape. In West Pomerania, F. catenulata also is found, although rarely, in peat bogs and bare peat (WARNSTORF 1885, WinKELMANN 1893, GóRSKi 2013).

\section{CHARACTERISTICS OF RESEARCH AREA}

Wigry National Park was established on 1 January 1989. It is one of the larger national parks in Poland, with an area of $150.8 \mathrm{~km}^{2}$. It is located in north-eastern Poland in the province of Podlaskie. In terms of geology, the park is situated in the Suwalsko-Mazurski elevation, a part of the East-European plate. This area represents an early post-glacial landscape that developed during the Würm glaciation. Geographically, this region is a part of Lithuania Lakeland. The early post-glacial land relief is the effect of extreme habitat variation. The part of the park located to the north (from the southern part of Lake Wigry) is geomorphologically greatly varied, with numerous moraine landforms, kames, eskers, subglacial meltwater channels and dead ice depressions, and it is a part of East Suwałki Lakeland (Pojezierze Wschodniosuwalskie). South of Lake Wigry is an outwash plain constituting the northern end of Augustów Plain (Równina Augustowska). In terms of climate, the region of Wigry National Park is strongly influenced by the continental block of Eurasia, which produces the most severe climatic conditions in the lowland part of Poland. The region is located in the so-called rain shadow of the Szeskie Hills (Wzgórza Szeskie), resulting in lower annual precipitation totals, with a multi-annual mean of $593 \mathrm{~mm}$.

Wigry National Park is composed of 42 lakes, including many dystrophic reservoirs, and they jointly cover $22 \%$ of the park area. The main river flowing through the park is the Czarna Hańcza, belonging to the Niemen basin. Other smaller rivers and streams, 
such as the Wiatrołuża, Kamionka, Gremzdówka and Samlanka, also flow through the park.

Forests predominate in the landscape of Wigry National Park, accounting for $60 \%$ of its area. The dominant forest communities are Serratulo-Pinetum and Tilio-Carpinetum. A characteristic feature of the Wigry National Park forests is a considerable share of coniferous forests and swamp forests, primarily Sphagno girgensohnii-Piceetum, Dryopteridi thelypteridis-Betuletum pubescentis, Vaccinio uliginosi-Pinetum and Ribeso nigri-Alnetum. The most valuable non-forest communities in the park include various forms of peatbogs, mainly transition mires and quaking bogs (7140), raised bogs (7110), alkaline fens with bog springs, sedges and mosses (7230) and calcareous fens (7210).

Considerable geomorphological variation in the land relief results in highly diverse habitat and microhabitat conditions, which is reflected in the great richness and diversity of natural resources of Wigry National Park. In turn, the unique climatic conditions of the park result in the floristic uniqueness of the area compared to the rest of lowland Poland.

Wigry National Park is protected within the framework of the Natura 2000 network as a special area of conservation (SAC PLH200004 Ostoja Wigierska) and a special protection area (SPA PLB200002 Puszcza Augustowska). In 1975, Lake Wigry was added to the list of the most valuable water bodies in the world by the International Union for Conservation of Nature (IUCN) within the Aqua Project. In 2002, Wigry National Park, by virtue of the Ramsar Convention, was classified as a wetland area of international importance.

\section{MATERIAL AND METHODS}

Studies were conducted during 2014-2015. The entire area of Wigry National Park was surveyed (Fig. 2). All forest complexes of the park were investigated, including both those on peatland and on mineral subsoils. Forest phytocoenoses with large shares of spruce and pine, whose decaying wood is a substrate for Fuscocephaloziopsis catenulata, were studied thoroughly. A disproportion between the number of surveyed sites in the northern and southern parts of the park is a consequence of the geomorphological and habitat diversity of the study area.

\section{RESULTS}

\section{GENERAL CHARACTERISTICS}

In Wigry National Park, Fuscocephaloziopsis catenulata was reported in 25 survey sites located in eight forest or forest-peatland complexes (Fig. 3). The most abundant locality, as manifested in the number of decaying logs overgrown by that species, is situ- ated at Jezioro Rzepiskowe Lake in phytocoenoses of boreal spruce forests on the western lake shore. Another area of greater accumulation of $F$. catenulata localities is associated with spruce coniferous forests in the Czarna Hańcza valley, both north and south of that river.

In the investigated area, almost all localities of F. catenulata are associated with decaying wood of pine or spruce logs. An exception in this respect is one locality in the Suche Bagno peat bog, where this species overgrew bare peat on an animal trail crossing the bog. Almost all localities of $F$. catenulata are located in phytocoenoses of the boreal spruce forest Sphagno girgensohnii-Piceetum.

\section{LIST OF LOCALITIES}

1. Forest section 276c, Suche Bagno peat bog, $\quad 54.003021^{\circ} \mathrm{N}, \quad 23.147120^{\circ} \mathrm{E}, \quad$ MGRS: 34UFE4072285991, Vaccinio uliginosi-Pinetum, bare peat, animal trail, 2014.07.11 (PG 78/2014)

2. Forest section $135 \mathrm{k}$, between Suchar Zachodni, Suchar Wschodni and Jezioro Wigry Lake, $\quad 54.042205^{\circ} \mathrm{N}, \quad 23.060491^{\circ} \mathrm{E}, \quad$ MGRS: 34UFE3491890181, Sphagno girgensohnii-Piceetum, decaying log, 2014.08.11 (PG 97/2014)

3. Forest section $157 \mathrm{~g}$, Suchar Wielki, $54.026579^{\circ} \mathrm{N}$, 23.060269 ${ }^{\circ}$, MGRS: 34UFE3495488442, Vaccinio uliginosi-Pinetum, decaying log, 2014.08.12 (PG 117/2014)

4. Forest section $165 \mathrm{~d}$, west of Jezioro Rzepiskowe Lake, $\quad 54.025722^{\circ} \mathrm{N}, \quad 23.069961^{\circ} \mathrm{E}, \quad$ MGRS: 34UFE3559288366, Sphagno girgensohnii-Piceetum, decaying log, 2014.08.12 (PG 124/2014)

5. Forest section $165 \mathrm{~d}$, west of Jezioro Rzepiskowe Lake, $\quad 54.025774^{\circ} \mathrm{N}, \quad 23.069893^{\circ} \mathrm{E}, \quad$ MGRS: 34UFE3558788371, Sphagno girgensohnii-Piceetum, decaying log, 2014.08.12 (PG 125/2014)

6. Forest section 165f, west of Jezioro Rzepiskowe Lake, $\quad 54.025114^{\circ} \mathrm{N}, \quad 23.070396^{\circ} \mathrm{E}, \quad \mathrm{MGRS}$ : 34UFE3562288299, Dryopteridi thelypteridis-Betuletum pubescentis, decaying log, 2014.08.12 (PG 126/2014)

7. Forest section $165 \mathrm{~d}$, west of Jezioro Rzepiskowe Lake, $\quad 54.025349^{\circ} \mathrm{N}, \quad 23.071592^{\circ} \mathrm{E}, \quad$ MGRS: 34UFE3570088327, Dryopteridi thelypteridis-Betuletum pubescentis, decaying log, 2014.08.12 (PG 127/2014)

8. Forest section 165f, west of Jezioro Rzepiskowe Lake, $\quad 54.025531^{\circ} \mathrm{N}, \quad 23.071295^{\circ} \mathrm{E}, \quad$ MGRS: 34UFE3568088347, Dryopteridi thelypteridis-Betuletum pubescentis, decaying log, 2014.08.12 (PG 128/2014)

9. Forest section $165 \mathrm{~d}$, west of Jezioro Rzepiskowe Lake, $\quad 54.026336^{\circ} \mathrm{N}, \quad 23.071080^{\circ} \mathrm{E}, \quad$ MGRS: 34UFE3566388436, Dryopteridi thelypteridis-Betuletum pubescentis, decaying log, 2014.08.14 (PG $166 / 2014)$ 


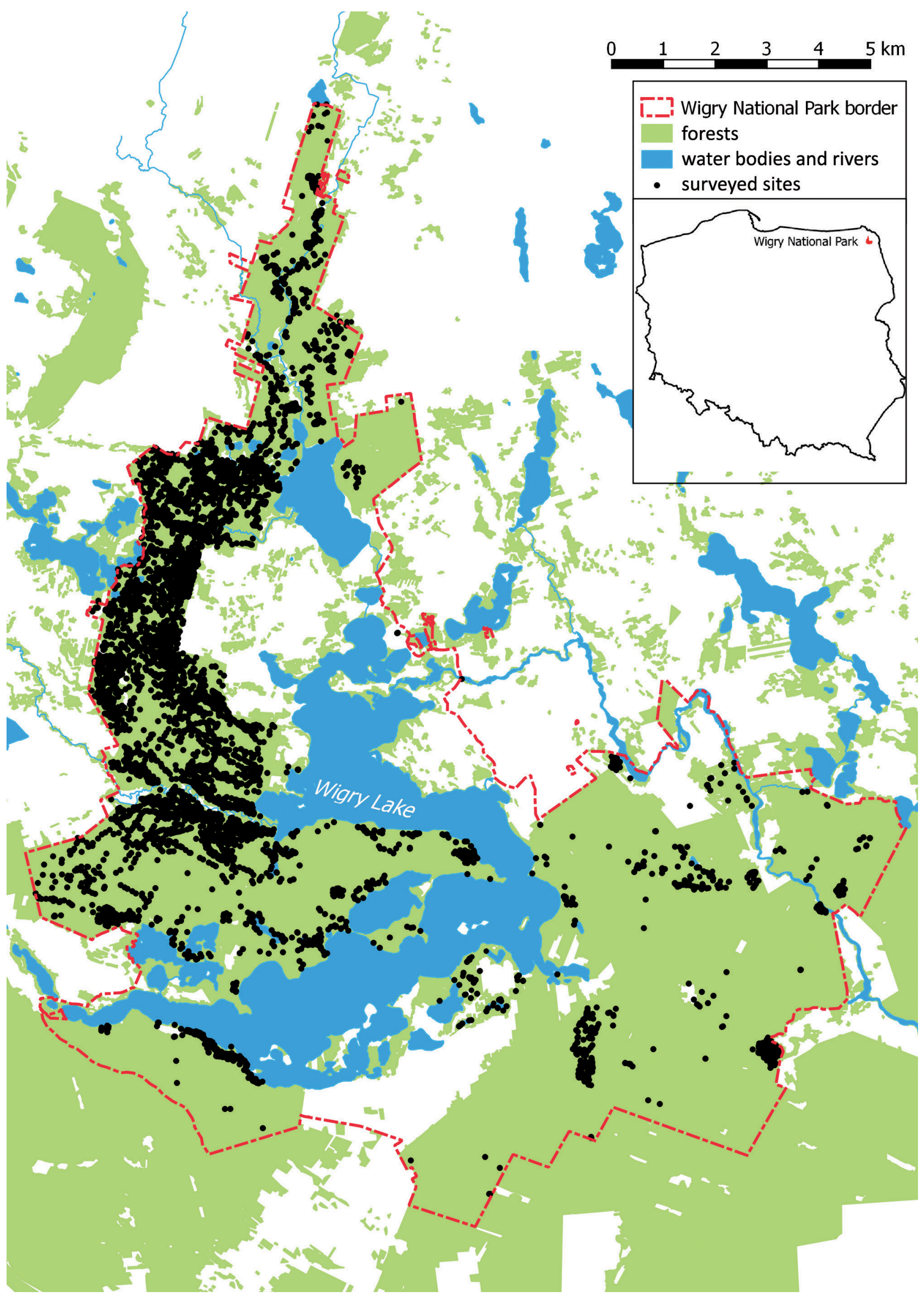

Fig. 2. Distributions of sites where liverworts were observed in the area of Wigry National Park 


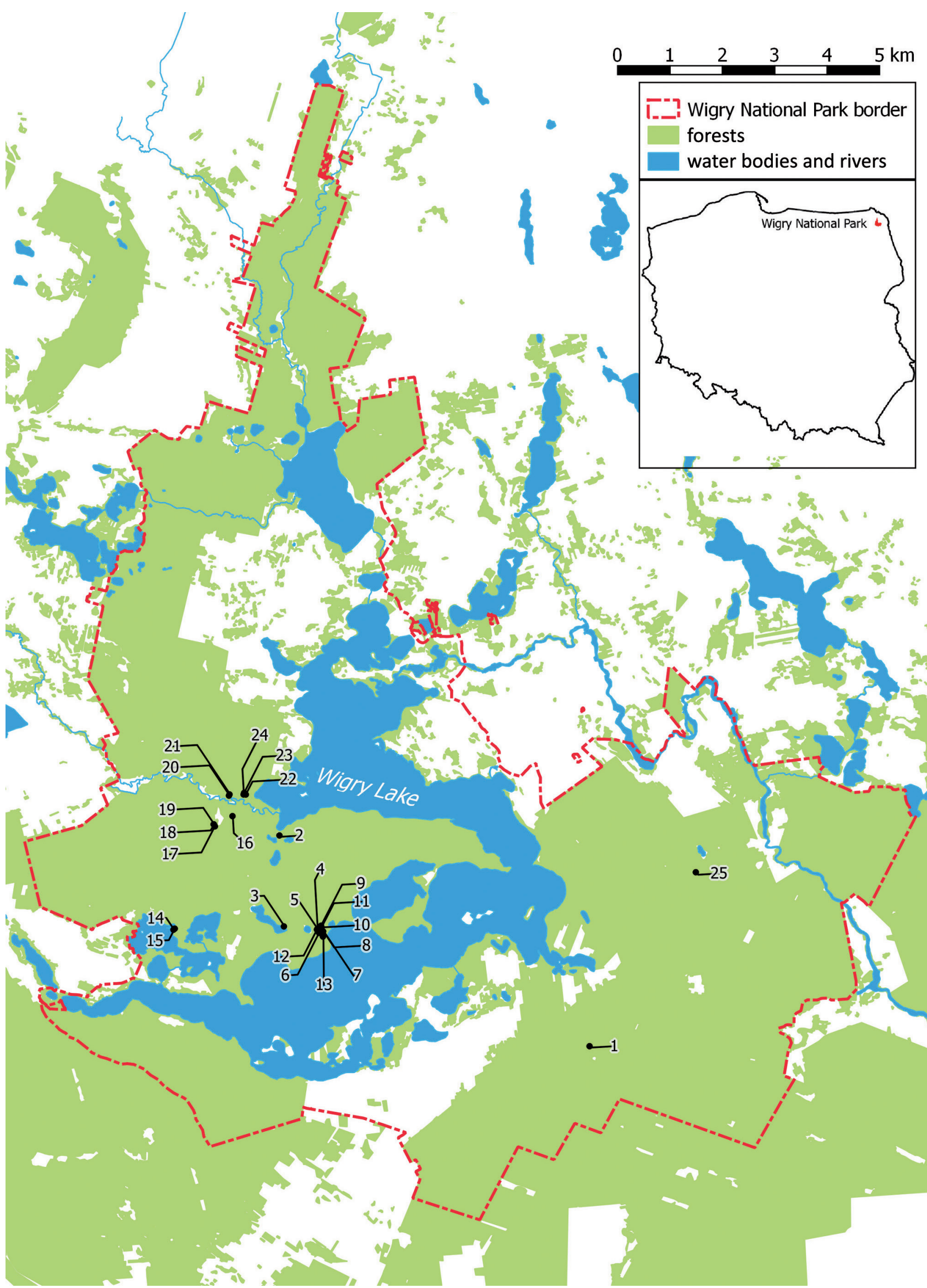

Fig. 3. Distribution of Fuscocephaloziopsis catenulata (Huebener) Váňa et L. Söderstr. in Wigry National Park (for details of the sites represented by nos $1-25$ see list of localities) 
10. Forest section $165 f$, west of Jezioro Rzepiskowe Lake, $\quad 54.026173^{\circ} \mathrm{N}, \quad 23.071052^{\circ} \mathrm{E}, \quad$ MGRS: 34UFE3566288418, Dryopteridi thelypteridis-Betuletum pubescentis, decaying log, 2014.08.14 (PG $167 / 2014$ )

11. Forest section 165f, west of Jezioro Rzepiskowe Lake, $\quad 54.026026^{\circ} \mathrm{N}, \quad 23.071181^{\circ} \mathrm{E}, \quad$ MGRS: 34UFE3567188402, Dryopteridi thelypteridis-Betuletum pubescentis, decaying log, 2014.08.14 (PG $168 / 2014$ )

12. Forest section $165 \mathrm{~d}$, west of Jezioro Rzepiskowe Lake, $\quad 54.025695^{\circ} \mathrm{N}, \quad 23.069829^{\circ} \mathrm{E}, \quad$ MGRS: 34UFE3558388362, Sphagno girgensohnii-Piceetum, decaying log, 2014.08.14 (PG 169/2014)

13. Forest section $165 \mathrm{~d}$, west of Jezioro Rzepiskowe Lake, $\quad 54.024448^{\circ} \mathrm{N}, \quad 23.071449^{\circ} \mathrm{E}, \quad$ MGRS: 34UFE3569388227, Dryopteridi thelypteridis-Betuletum pubescentis, decaying log, 2014.08.14 (PG 170/2014)

14. Forest section 134f, between Jezioro Muliczne Lake and Jezioro Długie Lake, $54.027097^{\circ} \mathrm{N}$, 23.028083 E, MGRS: 34UFE3284488439, Sphagno girgensohnii-Piceetum, decaying log, 2014.08.15 (PG 171/2014)

15. Forest section 134f, between Jezioro Muliczne Lake and Jezioro Długie Lake, $54.027269^{\circ} \mathrm{N}$, 23.028484 ${ }^{\circ}$ E, MGRS: 34UFE3287088459, Sphagno girgensohnii-Piceetum, decaying log, 2014.08.15 (PG 186/2014)

16. Forest section 129d, valley of the Czarna Hańcza river, south of the river, east of a peat-bog in the vally, $54.045976^{\circ} \mathrm{N}, 23.047148^{\circ} \mathrm{E}$, MGRS: 34UFE3403290575, Sphagno girgensohnii-Piceetum, decaying log, 2014.07.07 (PG 8/2014)

17. Forest section 122o, valley of the Czarna Hańcza river, south of the river, $54.044394^{\circ} \mathrm{N}$, 23.041853ㄹ, MGRS: 34UFE3369190389, Sphagno girgensohnii-Piceetum, decaying log, 2015.07.28 (PG 19/2015)

18. Forest section 122o, valley of the Czarna Hańcza river, south of the river, $54.044755^{\circ} \mathrm{N}$, 23.041590, MGRS: 34UFE3367290429, Sphagno girgensohnii-Piceetum, decaying log, 2015.07.28 (PG 22/2015)

19. Forest section 122o, valley of the Czarna Hańcza river, south of the river, $54.044752^{\circ} \mathrm{N}$, 23.041511 ${ }^{\circ}$ E, MGRS: 34UFE3366790428, Sphagno girgensohnii-Piceetum, decaying log, 2015.07.28 (PG 24/2015)

20. Forest section 128a, valley of the Czarna Hańcza river, north of the river, $54.049525^{\circ} \mathrm{N}$, 23.046467 E, MGRS: 34UFE3397690969, Sphagno girgensohnii-Piceetum, decaying log, 2015.07.29 (PG 53/2015)

21. Forest section 128a, valley of the Czarna Hańcza river, north of the river, $54.049725^{\circ} \mathrm{N}$, 23.046640ㅌ, MGRS: 34UFE3398790991, Spha- gno girgensohnii-Piceetum, decaying log, 2015.07.29 (PG 54/2015)

22. Forest section 121d, valley of the Czarna Hańcza river, north of the river, near Zatoka Hańczańska, $54.049544^{\circ} \mathrm{N}, 23.051392^{\circ} \mathrm{E}$, MGRS: 34UFE3429990980, Sphagno girgensohnii-Piceetum, decaying log, 2015.09.12 (PG 177/2015)

23. Forest section 121d, valley of the Czarna Hańcza river, north of the river, near Zatoka Hańczańska, $54.049852^{\circ} \mathrm{N}, 23.050927^{\circ} \mathrm{E}, \mathrm{MGRS}$ : 34UFE3426791013, Sphagno girgensohnii-Piceetum, decaying log, 2015.09.12 (PG 178/2015)

24. Forest section 121d, valley of the Czarna Hańcza river, north of the river, est of synoptic weather station, $54.049574^{\circ} \mathrm{N}, 23.050734^{\circ} \mathrm{E}$, MGRS: 34UFE3425690982, Sphagno girgensohnii-Piceetum, decaying log, 2015.09.12 (PG 180/2015)

25. Forest section $267 \mathrm{c}, 54.031748^{\circ} \mathrm{N}, 23.181000^{\circ} \mathrm{E}$, MGRS: 34UFE4284489254, Area of Strict Protection (in Polish: Obszar Ochrony Ścisłej) "Parowy", between Serratulo-Pinetum and Ribo nigri-Alnetum, decaying log, 2015.09.08 (PG 116/2015).

\section{ACKNOWLEDGEMENTS}

The paper was prepared within the framework of the project 'Topographic and habitat conditions for the occurrence of a liverwort Cephalozia catenulata (Huebener) Lindb. in the Wigry National Park in view of the determination of near-natural areas with characteristics of virgin primeval forest', financed from the forest fund of the State Forests (contract No. EZ.0290.1.24.2015).

\section{REFERENCES}

Bloch M., Karczmarz K., Sokołowski A. (1979): Nowe dane do flory mszaków północno-wschodniej Polski. II. Annales Universitatis Mariae $\mathrm{Cu}-$ rie-Skłodowska, Sectio C, Biologia 34(5): 47-53.

CieśLiński S., CZyŻEwska K., Faliński J.B., Klama H., Mutenko W., Żarnowiec J. (1996): Relicts of the primeval (virgin) forest. Relict phenomena. In: J.B. Faliński, W. Mułenko (eds). Cryptogamous plants in the forest communities of Białowieża National Park. Functional groups analysis and general synthesis (Project Crypto 3). Phytocoenosis 8 (N. S.), Archivum Geobotanicum 6: 197-216.

DüLl R. (1983): Distribution of the European and Macaronesian liverworts (Hepaticophytina). Bryologische Beiträge 2: 1-114.

Fudali E., Zubel R., Stebel A., RusińsKa A., Górski P., Vončina G., Rosadziński S., CYKowsKa-Marzencka B., Staniaszek-Kik M., Wierzcholska S., Wolski G.J., Wojterska M., Wilhelm M., Paciorek T., PIWOWARSKI B. (2015): Contribution to the bryoflora of the Roztocze National Park (SE Poland) - 
Bryophytes of the Świerszcz river valley. Steciana 19(1): 39-54.

GóRSKI P. (2013): Wątrobowce (Marchantiophyta) Leśnego Kompleksu Promocyjnego „Lasy Środkowopomorskie" (Pomorze Zachodnie). PGL Lasy Państwe Nadleśnictwo Karnieszewice, Wydawnictwo Uniwersytetu Przyrodniczego w Poznaniu, Sianów-Poznań.

GóRski P., PAWLIKowski P. (2014): 8. Fuscocephaloziopsis catenulata (Huebener) Váňa et L. Söderstr. (= Cephalozia catenulata (Huebener) Lindb.). In: P. Górski, A. Stebel, A. Rusińska (eds). New distributional data on bryophytes of Poland, 1. Steciana 18(2): 79.

GóRSKI P., VÁŇA J. (2014): A synopsis of liverworts occurring in the Tatra Mountains (Western Carpathians, Poland and Slovakia): checklist, distribution and new data. Preslia 86(4): 381-485.

Karczmarz K., SokoŁowski A. (1981): Nowe dane do flory mszaków północno-wschodniej Polski. III. Annales Universitatis Mariae Curie-Skłodowska, Sectio C, Biologia 36(11): 125-134.

Karczmarz K., SokoŁowski A. (1985): Brioflora projektowanego Wigierskiego Parku Narodowego. Annales Universitatis Mariae Curie-Skłodowska, Sectio C, Biologia 40(18): 193-213.

KlamA H. (1996): Wątrobowce (Hepaticae) Beskidu Żywiecko-Orawskiego (Karpaty Zachodnie). Monographiae Botanicae 79: 1-144.

Klama H. (2002a): Distribution patterns of liverworts (Marchantiopsida) in natural forest communities (Białowieża Primeval Forest, NE Poland). University of Bielsko-Biała, Bielsko-Biała.

Klama H. (2002b): Relikty puszczańskie we florze wątrobowców zbiorowisk leśnych Puszczy Białowieskiej. Zeszyty Naukowe ATH. Inżynieria Włókiennicza i Ochrona Środowiska 7(3): 244-260 .

Klama H. (2004): Wątrobowce (Marchantiophyta) Babiogórskiego Parku Narodowego. In: B.W. Wołoszyn, A. Jaworski, J. Szwagrzyk (eds). Babiogórski Park Narodowy. Monografia Przyrodnicza. Komitet Ochrony Przyrody PAN, Babiogórski Park Narodowy, Kraków: 333-356.

KLAmA H. (2006): Red list of the liverworts and hornworts in Poland. Czerwona lista watrobowców i glewików w Polsce. In: Z. Mirek, K. Zarzycki, W. Wojewoda, Z. Szeląg (eds). Red list of plants and fungi in Poland. Czerwona lista roślin i grzybów Polski. W. Szafer Institute of Botany, Polish Academy of Sciences, Kraków: 21-33.

Klama H. (2008): A contribution to the liverwort flora of the Tatra National Park (southern Poland). In: A. Stebel, R. Ochyra (eds). Bryophytes of the Polish Carpathians. Sorus, Poznań: 179-183.

Klama H. (2013): Wątrobowce Doliny Terebowca w Bieszczadach Zachodnich (Polskie Karpaty Wschodnie). Roczniki Bieszczadzkie 21: 42-56.
Mamczarz H. (1977): Brioflora i zbiorowiska mszaków Beskidu Sądeckiego. Część 1. Brioflora Beskidu Sądeckiego. Monographiae Botanicae 54: 3-158.

Mickiewicz J., Rejment-Grochowska I., SobotKa D. (1963): Materiały do flory mszaków Suwalszczyzny. Część 2 . Fragmenta Floristica et Geobotanica 9(2): 257-274.

MierZeŃSKA M. (1994): Wątrobowce Gorców. Fragmenta Floristica et Geobotanica Polonica 1: 235-346 .

Rejment-Grochowska I., Mickiewicz J. (1962): Materiały do flory mszaków Suwalszczyzny. Fragmenta Floristica et Geobotanica 8(1): 3-22.

StANIASZEK-KIK M. (2010): Liverworts on decaying wood and tree-fall disturbances in forest communities in the Karkonosze (the Sudetes, SW Poland). Acta Botanica Silesiaca 5: 131-156.

Stebel A. (2006): Atlas rozmieszczenia wątrobowców chronionych Polski w województwie opolskim. Centrum Dziedzictwa Przyrody Górnego Śląska, Materiały, Opracowania 9: 7-37.

Stebel A., Rosadziński S., Górski P., Fojcik B., Rusińska A., Vončina G., Szczepański M., Wilhelm M., Fudali E., Paciorek T., Staniaszek-Kik M., Zubel R., Piwowarski B., Wolski G., Salachna A., Smolińska D., PierśCiŃSKA A. (2013): Contribution to the bryoflora of the Świętokrzyski National Park (Central Poland). Roczniki Akademii Rolniczej w Poznaniu 392, Botanika-Steciana 17: 77-84.

SzweYkowski J. (1958): Prodromus Florae Hepaticarum Poloniae. Prace Komisji Biologicznej Poznańskiego Towarzystwa Przyjaciół Nauk 19: $1-600$.

Szweykowski J. (1960): Materiały do flory watrobowców Tatr. Prace Komisji Biologicznej Poznańskiego Towarzystwa Przyjaciół Nauk 21(3): 3-92.

SZWEYKOWSKI J. (2006): An annotated checklist of Polish liverworts and hornworts. - Krytyczna lista wątrobowców i glewików Polski. Biodiversity of Poland 4. W. Szafer Institute of Botany, Polish Academy of Sciences, Kraków.

Szweykowski J., Buczkowska K. (1996): Liverworts of the Bieszczady Zachodnie Range (Polish Eastern Carpathians) - a vanishing relict boreal flora. Fragmenta Floristica et Geobotanica 41(2): 865-934.

WARnstorf C. (1885): Moosflora der Provinz Brandenburg. Verhandlungen des Botanischen Vereins der Provinz Brandenburg 27: 1-94.

Wierzcholska S., Plášek V., Krzysztofiak A. (2010): Mszaki (Bryophyta). In: L. Krzysztofiak (ed.). Śluzowce Myxomycetes, grzyby Fungi i mszaki Bryophyta Wigierskiego Parku Narodowego. Przyroda Wigierskiego Parku Narodowego. Stowarzyszenie „Człowiek i Przyroda”, Suwałki: 229-298. 
Winkelmann J. (1893): Die Moosflora der Umgegend von Stettin. Programm des Schiller-Realgymnasiums zu Stettin (1893): 1-18.

Wiśniewski T., Rejment I. (1935): Das montane Element in der Lebermoosflora des Seengebietes von Suwałki. Bulletin de l'Académie Polonaise des Sciences et des Lettres, Série B 1: 11-31.
For citation: GóRsKi P., ROMAŃsKi M. (2016): Fuscocephaloziopsis catenulata (Huebener) Váňa et L. Söderstr. - a liverwort new to Wigry National Park (north-eastern Poland). Steciana 20(1): 4552. doi: $10.12657 /$ steciana.020.006 